\title{
Nuclear Nonproliferation Regime: Are New Institutions Needed?
}

\author{
Nükleer Silahların Yayılmasının Önlenmesi: Yeni Kurumlara İhtiyaç \\ Var mi?
}

\author{
Hasan SAYGIN* \\ Özüm Sezin UZUN**
}

\begin{abstract}
The existence of nuclear weapons, including the increasing of tactical nuclear weapons, is the major cause of a current nuclear threat at both the international and regional levels. In addition to the continuation of political and military motivations of states to acquire nuclear weapons, the institutional challenges of nuclear nonproliferation do also complicate this current problem. Even though the political and military motivations of states to acquire nuclear weapons are examined by the vast amount of studies, the effectiveness of international nuclear regime is rarely analyzed. Regarding the continuation of nuclear energy importance and the dual nature of nuclear technology, the necessity for reliable and effective institutions to prevent proliferation of nuclear weapons became more apparent. Therefore, this article aims to shed light on the ineffectiveness of the current international nuclear regime and the need for new institutional mechanism. This article analyzed the effectiveness of international nuclear regime measuring its capability of problem-solving, reducing nuclear motivations of states, providing legal framework and verification process, and creating and consolidating normative principles. While the nuclear regime could partly be seen as effective regarding the low number of current nuclear weapon states than the expected numbers in 1960s, it faces with serious challenges in solving the nuclear problem. One of the challenges emerges because of the lack of universal acceptance of the international treaties and organizations. The regime has also not effectively addressed to reduce the nuclear motivations of states. Even though it has provided legal framework and verifying process, there are still difficulties to detect nuclear activities for military purposes. Lastly, the regime has effectively created the non-use and deterrence norms, while failed to create and consolidate the nonproliferation norm, based on total elimination of nuclear weapons. In fact, this article argues that the current institutional
\end{abstract}

* $\quad$ Prof. Dr., İstanbul Aydın Üniversitesi, İstanbul hasansaygin@aydin.edu.tr, Orcid: 0000-0003-2479-7635

* Dr. Öğr. Üyesi, İstanbul Aydın Üniversitesi, Siyaset Bilimi ve Uluslararası İlişkiler Bölümü, İstanbul ozumuzun@aydin.edu.tr, Orcid: 0000-0002-8673-2151 
mechanism should be revised considering the causes of threats; furthermore, new mechanisms should be established in order to meet the newly emerged challenges in the post-Cold War era. In that respect, this article firstly analyzes the ineffectiveness of current international nuclear regime in order to demonstrate the urgent need for a paradigm shift. Then, it suggests a new multilateral mechanism, as an attempt to contribute to create a discussion platform for alternative institutional mechanisms.

Keywords: international nuclear regime, effectiveness of nuclear regime, nuclear weapons, nonproliferation of nuclear weapons

\section{Öz}

Uluslararası ve bölgesel düzeyde, artan taktiksel nükleer silahlar dahil olmak üzere, nükleer silahların varlığı nükleer tehditin en önemli unsurlarındandır. Devletlerin nükleer silah elde etmek için siyasi ve askeri motivasyonlarının yanında, nükleer silahların yayılmasının önlenmesi konusunda faaliyet gösteren kurumlardan kaynaklı sorunlar da mevcut sorunu daha fazla karmaşıklaştırmaktadır. Nükleer silahların yayılmasıyla ilgili çalışmaların birçoğu ülkelerin bu silahları edinme motivasyonları üzerinde dururken nükleer silahların yayılmasını önlemek için kurulmuş olan mevcut kurumsal yapıların verimliliğini tartışmamaktadır. Nükleer enerjinin devam eden önemi ve nükleer teknolojinin ikiyüzlü doğası dikkate alındığında, nükleer silahların yayılmasını önlemek için güvenilir ve verimli kurumlara olan ihtiyaç daha fazla hissedilir olmuştur. Bu nedenle bu makale, uluslararası nükleer rejimin verimliliğini problem çözme, ülkelerin nükleer motivasyonunu düşürme, yasal çerçeve sunma ve nükleer silahları tespit ve denetleme süreçlerini oluşturma, ve normatif prensipleri yaratma ve sağlamlaştırma kapasitesi ölçülerek analiz etmiştir. Mevcut durumda nükleer silah sahibi ülkelerinin sayısının, 1960'larda öngörülenden az olması nedeniyle nükleer rejim verimli olarak görülse de nükleer problemi çözmede ciddi sorunları vardır. Bu sorunlardan bir tanesi, nükleer silahların yayılmasının önlenmesini amaçlayan uluslararası antlaşma ve organizasyonların tüm devletler tarafından kabul görmemesinden meydana gelmektedir. Rejim, ülkelerin nükleer motivasyonlarını düşürme konusunda da verimli olamamıştır. Yasal çerçeveyi ve denetim mekanizmalarını sunmuş olsa da nükleer silahları tespit ve denetim süreçlerinde tam başarıya ulaşamamıştır. Son olarak nükleer silahları kullanmama ve caydırıcılık normlarını yaratmış olsa da nükleer silahların tamamen yok edilmesine dayanan yayılmanın önlenmesi normunu oluşturamamıştır. Sonuç olarak, bu makale, neden nükleer silahların yayılmasının önlenmesi için yeni bir kurumsal mekanizmaya ihtiyaç olduğu sorusu çerçevesinde nükleer silahların yayılmasının önlenmesinde Soğuk Savaş dinamikleriyle kurulan mevcut kurumsal mekanizmaların, günümüzün yeni tehditleri dikkate alınarak tekrar gözden geçirilmesi gerektiğini savunmakta, hatta yeni mekanizmaların kurulması gerektiğini iddia etmektedir. Bu nedenle, makale acil olarak paradigma değişikliğine ihtiyaç duyulduğunu göstermek amacıyla öncelikle mevcut uluslararası nükleer rejimin verimliliğini analiz etmiştir. Daha sonra alternatif kurumların kurulabilmesi için tartışma platformu oluşturmaya katkı sağlayabilmek için yeni bir çok-taraflı mekanizma önermektedir.

Anahtar Kelimeler: uluslararası nükleer rejim, nükleer rejimin verimliliği, nükleer silahlar, nükleer silahların yayılmasının önlenmesi

\section{Introduction}

Many believe that today the global insecurity has been rising and the existence of nuclear weapons makes the instabilities and conflicts more dangerous. Even though the political and military motivations of states to acquire nuclear weapons are examined by the vast amount of studies, the effectiveness of international nuclear regime is rarely analyzed. Regarding the continuation of nuclear energy importance and the dual nature of nuclear technology, the necessity for reliable and effective institutions to prevent proliferation of nuclear weapons became more apparent. At 
the present, however, there is a neurotic symptom in the international nuclear nonproliferation regime; everyone agrees that the tension in the global nuclear order has been rising because of the lack of progress toward disarmament and both the existence and proliferation of nuclear weapons would result in borderless damages of humanity, the multinational attempts to eliminate all nuclear weapons without exception are still inconclusive. Moreover, the international nonproliferation treaties and organizations, which are now in effects, are rarely criticized.

The motivations of states and the systemic factors on states to acquire nuclear weapons have been at the center of the security studies concerns. Within this framework, realists have primarily focused on the anarchical structure of international system, in which the primary motivation of states is to maximize their own military capabilities. It is certain that acquiring nuclear capability has been equalized with power, providing military superiority with a deterrence capability and political bargaining power. Therefore, the search for accessing nuclear capability was spread out. In contrast to the realist explanations, which have traditionally tended to downplay the role of norms in understanding the proliferation process of nuclear weapons, the recent studies have demonstrated the roles of normative factors in both nuclear proliferation and non-use of nuclear weapons. Within this framework, the establishment of multilateral mechanisms, including treaties and organizations, positively contributed to create non-use norm of nuclear weapons. However, the continuation of nuclear proliferation and the emergence of new threats such as the possibility of nuclear capable terrorism have raised the questions over the effectiveness of existing institutional mechanisms and norms.

International institutional mechanisms were founded regarding the needs of Cold War period and certainly became insufficient to deal with current proliferation challenges. Arguing the necessity to revise the current international institutional mechanisms of nonproliferation, this article seeks to answer to the following questions: Are the institutional mechanisms in nonproliferation effective? If not, what are the main challenges to the international nonproliferation regime? What would be an alternative nonproliferation institutional mechanism to deal with the current challenges to international security?

While answering the abovementioned research questions, this article will analyze the effectiveness of international nuclear regime measuring its capability of problem-solving, reducing nuclear motivations of states, providing legal framework and verification process, and creating and consolidating normative principles. Within that framework, this article will firstly introduce the existing, but deadlocked international mechanism. Secondly, it will analyze the challenges that international nonproliferation regime has now been facing with. These two parts complement each other to demonstrate the urgent need for a paradigm shift, since the current international nonproliferation regime came to a deadlock both in cognitive and institutional means. Furthermore, the first two parts will focus on the measurement criteria of the current nuclear regime to demonstrate why a new multilateral mechanism is needed to deal with the newly emerged challenges. Hence, the final part will suggest a new multilateral mechanism, as an attempt to contribute to create a discussion platform for alternative institutions. 


\section{Assessment of Current International Nuclear Regime: Effective or Not?}

Regarding the imbalance between the intentions of multilateral initiatives and their outcomes, scholars and experts have been questioning the effectiveness of institutions in the international nonproliferation regime. Young and Levy defines (1999, p.1) an effective international regime as: "A regime that channels behavior in such a way as to eliminate or substantially ameliorate the problem that led to its creation is an effective regime. A regime that has little behavioral impact, by contrast, is an ineffective regime." The measurement of effectiveness of international regime, mentioned by Young and Levy (1999, pp.4-6), provides a beneficial ground for discussing on the criteria of the effectiveness of international nuclear nonproliferation regime. They mentioned problem-solving approach, legal approach, economic approach, normative approach and political approach to measure the effectiveness of international regime. Since, the international regimes aim at responding to particular problems, its problem-solving capability is one of the criteria that could be used for measuring its effectiveness. The other criterion is the capability of international regime to create legal framework for the elimination of the problem. Thirdly, the economic cost would also be another criterion to determine the effectiveness of the international regime. Within that framework, if the expected outcome is met by the least cost with the other things being equal, the international regime could be evaluated as effective. The capability of international regime in creating normative principles is another measurement criterion of the effectiveness. Finally, changes in the behavior of actors are one the measurement items of the effectiveness of international regime.

\section{Solving the Nuclear Problem}

The literature on the effectiveness of international nuclear regime mostly questions what the future of regime would be, since it is perceived as in crisis. Dhanapala argues that the current debate between unilateralists and multilateralists has been shaping the future of the global nuclear nonproliferation regime. (Dhanapala, 2001, pp. 1-2) According to unilateralists, international relations dominated by sovereign states, each seeking for survive or maximize their power in an anarchic world. Thus, they perceive nonproliferation as a national policy, which makes nuclear nonproliferation regime as the sum of specific policies and commitments of individual states to halt, slow or to block the ability of other governments to acquire nuclear weapons. In that respect, they see nonproliferation as a mean to end the maximization of national interest. According to multilateralists, however, ideas can play crucial role in benefiting interests. Therefore, they see nonproliferation as a way to ensure common security benefits through eliminating nuclear weapons.

The maintenance of regime is quite dependent on its effectiveness. By the entrance into force of Nuclear Nonproliferation Treaty (NPT) in 1970 and then the establishment of international institutional mechanisms for providing both rules and verification processes demonstrate the effective side of the international nuclear regime. However, it seems that the regime is not 
sufficient to solve the problem, which is caused by the existence of nuclear weapons. Regarding the actual numbers of nuclear weapon states, which is now much low than the expected numbers in $1960 \mathrm{~s},{ }^{1}$ it could be said that the international nuclear regime has been effective in controlling the trend of proliferation of nuclear weapons. In spite of having this positive side, there are serious challenges in the problem-solving capability of existing international nuclear regime. It is known that the elimination of nuclear weapons has not been accomplished yet.

The ineffectiveness of the nuclear regime in solving the problem majorly caused by the existence of nuclear weapons, specifically tactical nuclear weapons in the military arsenals, and the newly emerged proliferators in addition to states. There are several reasons of a state to acquire nuclear weapons; however, the threat perception is the causa sine quo non. In other words, the domestic and regional environments are significant determinants causing a country to develop nuclear weapons. (Homan, 2013, p. 63) When a state suspects its neighbors that have had built or been acquiring nuclear weapons, its adherence to any treaty, including the NPT, would not be sustained regarding its threat perception from a nuclear-armed neighbor. (Braun and Chyba, 2004, p. 42) Therefore, the acquisition of nuclear weapons by a state will inevitably lead to the newly emerged proliferators. In that respect, the lack of universal membership to the nuclear nonproliferation treaties and initiatives also demonstrates the risk of emergence of new proliferators. In fact, the risk of nuclear attack stems from three security challenges: 'existing nuclear weapons, the proliferation of nuclear weapons, and civilian nuclear facilities which may hide a clandestine weapons program.' (McCoy, 2007, p. 261)

Although nuclear-weapon states agreed to eliminate their nuclear arsenals at the 2000 Review Conference of the NPT, they intend to keep them and furthermore acquire more tactical nuclear weapons. United States, for instance, has been investing in its nuclear weapons program due to the so-called increasing threats from 'rogue states.' US President Obama declared, 'the fundamental role of U.S. nuclear weapons will continue, as long as nuclear weapons exist, to deter nuclear attack on the United States, our allies, and partners.' ('Obama Prague Speech on Nuclear Weapons", April 2010: vii) ElBaradei, former Director General of the International Atomic Energy Agency (IAEA), mentioned that the United States has been employing a double standard by not actually eliminating its own arsenal of nuclear weapons while attempting to restrain other countries from acquiring nuclear weapons. Therefore, Galtung and Portales stated that "ours is the age of militarization (...) There is no doubt that the military formation is a major part of contemporary

1 In 1960s, 20 or 30 countries were expected to acquire nuclear weapons. Today, eight countries have nuclear weapons. Five of them, which are the United States, Russia, China, France and the United Kingdom, are recognized by the Treaty on the Non-Proliferation of Nuclear Weapons (NPT) as nuclear weapon states and have duties not to transfer nuclear weapons or other nuclear explosive devices and not in any way to assist or encourage a non-nuclear weapons state to acquire nuclear weapons. India and Pakistan have nuclear capability, while they have not yet openly deployed any weapons. Israel as well is widely believed to have nuclear weapons, but neither accepts nor denies their existence. Avner Cohen advocates in his book, titled "Israel and the Bomb," that the Israeli initiative to acquire nuclear weapons was started by the classified agreement between Ben Gurion and Shimon Peres in 1947, before the establishment of the Israeli state. India, Pakistan and Israel are de facto nuclear weapon states and reject to be a party to the NPT. Apart from these countries, Iran has been suspected of violating its obligations to acquire nuclear weapons and North Korea has conducted three nuclear weapons tests in 2006, 2009 and 2013. 
society," regarding the militarization trend. (Eyre and Suchman, 1996, p. 80) (Pullinger, 2003, p. 55) Not only United States, but also NATO and Russia keeps at least the tactical nuclear weapons in their military arsenals. In addition, it is known that France, China, Pakistan, India and Israel have tactical nuclear weapons. (Kristensen, 2012, pp. 8-9)

The continuation of the role of nuclear weapons in the military, specifically in the nuclearweapon states, weakens the capability of problem-solving of international nuclear regime. While tactical nuclear weapons, for instance, reduce the disproportionate nature of nuclear weapons with the advanced technology, they increase the risk of the use of nuclear. That is why US President Obama emphasized the increasing risk of a nuclear attack, while the risk of a global nuclear war has decreased. ("Obama Prague Speech on Nuclear Weapons": vii) Furthermore, the less destructive power of tactical nuclear weapons would result in lesser consideration about the usage of them. The lack of a common definition of what is meant by tactical nuclear weapons, for instance, also creates a difficulty for international nonproliferation efforts. Even though Washington and Moscow agreed on a common definition of nuclear delivery vehicles based on the range during the Cold War, they did not have a common ground for tactical nuclear weapons. In the aftermath of the Cold War, they started to remove the least secure tactical nuclear weapons through unilateral presidential initiatives, which did not include the common definition of tactical nuclear weapons and verification process. Only recently, US, Russian and NATO officials attempted to clarify definitions of tactical nuclear weapons. Lastly, the uncertainty about the number of tactical nuclear weapons creates the risk for the effectiveness of international nuclear regime. Although it is known that tactical nuclear weapons have been acquired by several states, the exact number of tactical nuclear weapons they have, is not disclosed. Keeping the number of these weapons secret complicates the nuclear nonproliferation efforts of institutions. This ambiguity increases the verification problem and the risk of theft by terrorists, which increases the risk of a possible nuclear attack in near future.

Even though the proliferation of nuclear weapons is not a new phenomenon, the risk of an attack with nuclear weapons, especially by the terrorist groups is new. At the time when the NPT came into effect, the main aim was to prevent industrially advanced countries to acquire nuclear weapons, as Diyakov emphasizes. (Diyakov, 2010, p. 120) However, today's proliferators would include not only states, but also fundamentalists and terrorists, which makes the risk of a nuclear weapon explosion greater than as previously assumed. States have traditionally been perceived as the main actors that would use nuclear weapons. However, terrorists would likely be the next users of the nuclear weapons. Nuclear terrorism would be the outcome of the successful nuclear acquisition attempt of outsider or insider theft, from the black market and from a state in possession of such items. Regarding these four means of nuclear terrorism, Bunn demonstrates the factors that increase the risk of nuclear terrorism. Among these, the perception of terrorist group about the nuclear weapon or material plays great role. If it is seen that nuclear capability would provide a strategic advantage against governments, then the risk of nuclear terrorism would increase. (Bunn, 2006, p. 110) 
The number of terrorist groups interested in getting and using nuclear weapons was zero from the beginning of the nuclear era to the late 1980s. (Bunn, 2006, p. 108) The likelihood has been growing as more and more countries have produced nuclear weapons or materials. Therefore, the policy measures should aim to reduce the possibility of a successful nuclear acquisition of terrorists. One of the measures would be to consolidate the norm of nuclear nonproliferation because the existing non-use and deterrence norms of nuclear weapons would not be sufficient to prevent any use of nuclear weapons by terrorist organizations. As Doyle (2013, p. 16) mentions, "more nuclear materials are being produced, more knowledge relevant to the construction of nuclear weapons is being dispersed, and terrorist organisations are becoming more interested in acquiring nuclear capabilities." Therefore, the priority of international nonproliferation efforts should eliminate stockpiles of nuclear weapons and materials throughout the world.

\section{Providing Legal Framework and Verification Process}

The international nuclear nonproliferation efforts, by the entrance of NPT into force in 1970, have existed for nearly fifty years and included a number of multilateral mechanisms to prevent proliferation of nuclear weapons. The agreement on the NPT has been one of the crucial steps to prevent nuclear proliferation. Under the terms of NPT, states were divided into two; namely nuclear weapon states and non-nuclear weapon states. The Treaty aims to prevent horizontal and vertical proliferation of nuclear weapons. Regarding the first goal in preventing horizontal proliferation, it banned nuclear weapon states to assist non-nuclear weapon states to acquire nuclear weapons and to transfer nuclear weapons or its explosive devices to them. Regarding the second objective in preventing vertical proliferation, it aims to eliminate all nuclear weapons.

In addition to the NPT, the International Atomic Energy Agency (IAEA) has also become a key organization in the nonproliferation regime, implementing the verification process of nonproliferation within the framework of NPT. In accordance with the aim of preventing nuclear weapons proliferation, the IAEA aims "to accelerate and enlarge the contribution of atomic energy to peace, health and prosperity throughout the world" and to 'ensure, so far as it is able, that assistance provided by it or at its request or under its supervision or control is not used in such a way as to further any military purpose.' (The Statute of IAEA, Article II, http://www.iaea. org/About/statute.html) There have also been additional international attempts to control export of nuclear materials between states. The Zangger Committee, then renamed as Nuclear Suppliers Group and the Wassener Agreement on Export Controls for Conventional Arms and Dual Use Goods and Technologies, for instance, is one of them and attempted to control over the export of sensitive nuclear-related materials and technologies. Despite these multilateral mechanisms, proliferation of nuclear weapons and the search for an indigenous nuclear fuel cycle by several states could not be prevented.

Effectiveness of a regime is also dependent on the member states positive perception on the fulfillment of its rules by all states. According to Sauer (2006, p. 334), one of the main challenges 
is now caused by the feeling of member states that the other would not fulfill the obligations of the nuclear nonproliferation regime. Zaborsky argues as well (1998, p. 92), one of the ineffectiveness lies in the text of the NPT, which discriminates nuclear states versus non-nuclear weapon states. While this separation could have some sense in time of writing the articles of the treaty for preventing nuclear proliferation both vertically and horizontally, it is seen in time that the unachieved objectives have created new challenges. For instance, the discriminatory text of the NPT leads some countries not to ratify it, which creates the lack of universal acceptance. Moreover, the NPT does not address to the threats caused by near-nuclear or threshold states. ${ }^{2}$ Last but not least, while the NPT Review Conferences extended the NPT indefinitely and unconditionally in 1995 , it does not sufficiently address to strengthen regime's capability to provide legal framework and verification process.

\section{Reducing Nuclear Motivations}

Proliferation of nuclear weapons is a complex phenomenon to be explained fully by any single explanation. Traditionally, the anarchic feature of international system, the national security and the competition of interests among the internal bureaucracy were observed as the main reasons for proliferation of weapons. From a realist approach, for instance, nuclear proliferation is an outcome of anarchical system, which necessitates the states to strengthen their military capability in order to maximize their own national interests. Furthermore, states would never be completely secure in an anarchical structure that inevitably causes to the proliferation of nuclear weapons.

As a complementary approach to the realist standpoint, constructivists have focused on how particular social and cultural meanings, namely normative understandings, have affected the proliferation of weapons. In the view of constructivism, "norms shape conceptualizations of interests through the social construction of identities." (Price and Tannenwald, 1996, p. 125) The constructivist approach emphasizes the outcome of normative structure, which is formed by collective expectations for the appropriate behavior of actors with a constructed identity. Eyre and Suchman (1996, pp. 86-87) argue that socially constructed meanings that have associated with weapons are the main factors for the proliferation. According to them, linking conventional weapons with sovereign status as a nation, with modernization and social legitimacy have caused to the proliferation. Regarding nuclear weapons, it seems that the effect of the normative structure is not different. Acquiring a nuclear weapon has been associated with the status of a 'superpower' or 'regional power'. Scott Sagan (1996/97, p. 55), for instance, argues that the determinant force behind the proliferation of nuclear weapons is more than for national security. According to him, nuclear weapons serve both as the political tool in internal bureaucratic struggles and as international normative symbols of modernity and identity.

2 Near-nuclear states have no nuclear programs at all and no intention to have nuclear weapon capability in the near future, despite their developed technical ability to build nuclear weapons. Threshold states, however, have highly developed nuclear programs for peaceful purposes, which would easily be transformed for military purposes. 
NPT has been more focused on the prevention of nuclear proliferation horizontally, ignoring vertical proliferation. It aims to prevent non-nuclear weapon states to acquire technical ability to produce nuclear weapons, rather than to end, or at least minimize, states' nuclear motivations. It is certain that the technical challenges have been at the top of the reasons for the restrictive factors of nuclear proliferation. However, in the last fifty years, it is observed that if a state has strong nuclear motivation, it would find solutions to overcome technical challenges to acquire nuclear capability, including via illegal means. Therefore, the effective solution should be to eliminate, or at least to reduce, politico-military motivations of states to acquire nuclear weapons. According to Zaborsky (1998, p. 2), the first dilemmas of nonproliferation lies on the answer of "which government is more reliable and safe in nonproliferation regime terms: a government with no political and security incentives to build WMD [weapons of mass destruction], or one with no technical capabilities to build them." Current institutional mechanisms have rarely addressed to the political motivations of states for nuclear proliferation, which creates another ineffectiveness of the regime. They mainly focused on strengthening verification measures in order to prevent them to achieve technical capabilities for military purposes, rather than to reduce motivations of states to acquire nuclear weapons.

\section{Creating and Consolidating Normative Principles}

Understanding the normative factors that work against the use of nuclear weapons is as important as understanding why states proliferate. It is noteworthy to mention that international nonproliferation efforts have successfully created nuclear taboo. As in the case of nuclear proliferation, there are no exclusive explanations why states voluntarily forego the use of nuclear weapons. Press, Sagan and Valentino (2013) mention three broad theoretical explanations to understand states' stance towards nuclear weapons. The first explanation emphasizes the 'logic of appropriateness', in which the use of nuclear weapons is determined by the decision of states about what kinds of behavior are appropriate. In accordance with this first explanation, states do not decide to use nuclear weapons because of the conventional wisdom about the non-use norm of nuclear weapons. The records of political discussions during the Spring of 1953 on how to end the Korean War demonstrates the determinant impact of the normative issues on the behavior of states. Price and Tannenwald (1996, p. 138) quote that Eisenhower and Dulles were more concerned about the possible negative public opinion on nuclear use than any material concern. In that respect, the consolidation of a 'nuclear taboo' at the global level led the legitimacy and legality of nuclear weapons to be decreased. (Tannenwald, 1999, pp. 435-436) Since civilians are no longer seen as the legitimate target at war, the disproportionate nature of nuclear weapons made them as an unacceptable weapon of war, so a moral country does not want to take the risk of killing noncombatants.

In contrast to this explanation, the second view mentions the 'logic of consequences', in which the use of nuclear weapons is determined by the decision of states taken after cost-benefit calculation. This perspective advocates that states do not use nuclear weapons because they assessed that the 
destructiveness of nuclear weapons would not serve the objective. Brazil decided to dismantle nuclear weapon program and end its nuclear rivalry with Argentine in 1990 was partly as a result of such 'logic of consequences'. Moreover, adding the acceptance of the use of nuclear energy only for civilian purposes to the 1998 Constitution demonstrates how norms are seen as powerful in nonproliferation efforts. ${ }^{3}$

The last view argues that the choices of states about using nuclear weapons are also determined by the 'logic of consequences,' but suggests the preferences of states as an outcome of strategic interaction with others. From this standpoint, states may forego the use of nuclear weapons not to become a precedent.

All these theoretical explanations contribute to understand why states proliferate and why they voluntarily decline the use of nuclear weapons. It seems that there is a relatively well-established non-use and deterrence norms of the nuclear weapons, however, it is uncertain to what extent these norms would prevent a nuclear attack in the future. After the United States dropped the atomic bomb in Hiroshima and Nagasaki in 1945, the destructive effects of nuclear weapons created a global stance against the use of nuclear weapons. Since there is not a legal prohibition against the use of nuclear weapons, the non-use norm exists as a de facto norm.

The central idea about the non-use of nuclear weapons lies on two basic assumptions. The first is identifying nuclear weapons as 'weapons of mass destruction,' which delegitimizes them as weapons of war; the second is based on the norm of deterrence, which implies that the outcome of the use of nuclear weapons would be so extreme that prevent actors from taking such a decision. Even though the deterrence has been perceived as one of the main pillars of the non-use norm, it does not suggest neither sufficient explanations to the non-use in cases where there is no fear of nuclear retaliation, the attacks of non-nuclear states against nuclear states and the relatively few number of states that seek to have a nuclear deterrent capability. (Tannenwald, 1999, pp. 433-434) In addition, the deterrence norm would not work for the prevention of a nuclear attack by terrorists and would fail either because of a series of mechanical and human errors that lead to take irrational decisions. Therefore, it would be costly to maintain nuclear arsenal believing in the deterrence norm. Furthermore, the possibility of public support to the usage of nuclear weapons when the nuclear weapons are perceived as militarily useful demonstrates the weakness of current international nonproliferation regime. (Press, Sagan and Valentino, 2013, pp. 9-13) These challenges prove that the non-use norm of nuclear weapons is weak and not reliable for the future of international nonproliferation regime.

3 Brazil Constitution, Article XXIII - operate nuclear energy services and facilities of any nature, exercise state monopoly over research, mining, enrichment and reprocessing, industrialization and trade in nuclear ores and their by-products, taking into account the following principles and conditions: a) all nuclear activity within the national territory shall only be admitted for peaceful purposes and subject to approval by the National Congress; $b$ ) under regime of permission, authorization is given for the utilization of radioisotopes in research and for medical, agricultural and industrial use; c) under regime of permission, authorization is given for production, commercialization and utilization of radioisotopes with half-life equal to or shorter than two hours; d) civil liability for nuclear damages does not depend on the existence of fault. Available at: http://www.v-brazil.com/government/ laws/titleIII.html (Accessed 15 October 2013) 


\section{Possibility of a New Multilateral Mechanism}

Regarding the insufficiency of current treaties and institutions, an alternative multilateral mechanism should be founded on both new normative and institutional bases. On the one hand, the nonproliferation norm, rather than the current non-use or deterrence norms, should be prioritized in order to eliminate all nuclear weapons without exception. On the other hand, institutional mechanism should be re-constructed in order to minimize the risk of a nuclear attack. Graphic 1 illustrates one of the possible alternative mechanisms for nuclear nonproliferation.

\section{Graphic 1: An Alternative Mechanism for Nuclear Nonproliferation}

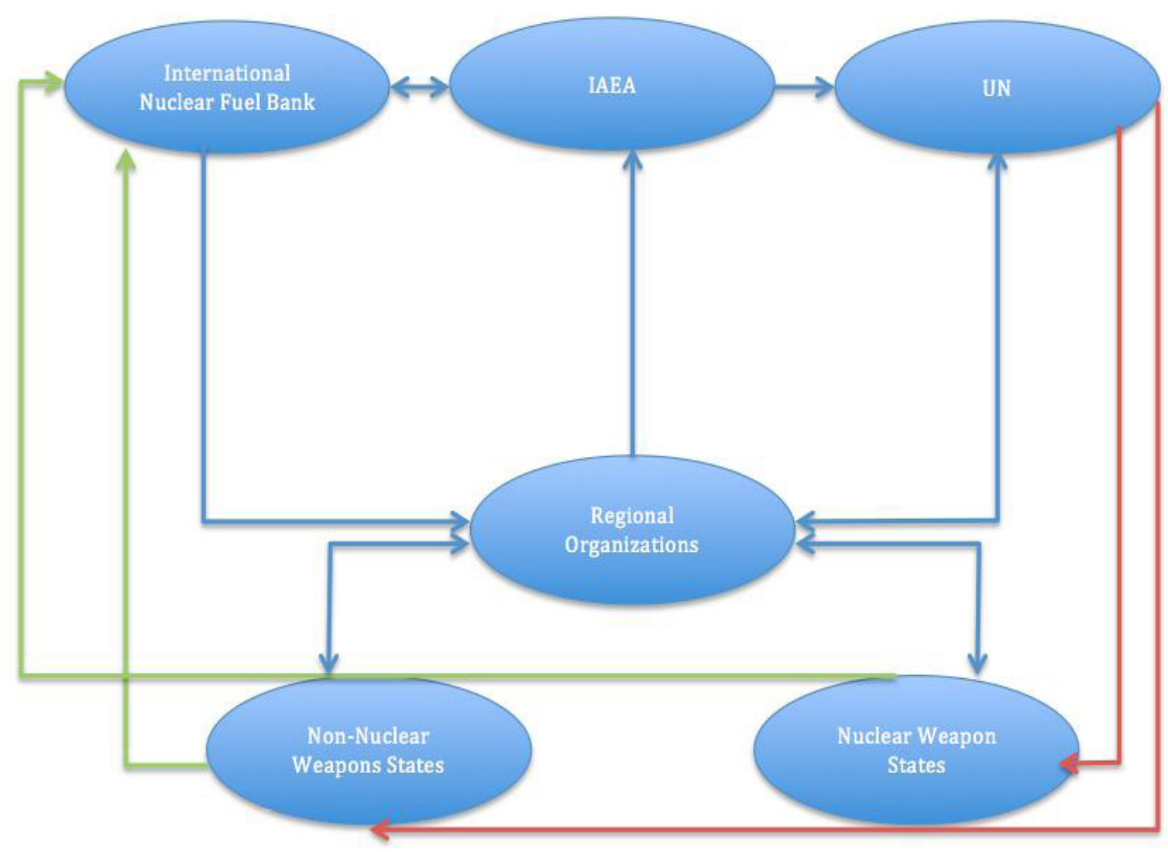

An alternative mechanism should be based on three levels; international, regional and domestic levels. At the international level, the United Nations (UN), the International Atomic Energy Agency (IAEA) and an International Nuclear Bank should operate. At the regional level, regional organizations should work for more transparent nonproliferation efforts. At the domestic levels, both nuclear-weapon states and non-nuclear-weapon states should take nonproliferation policies.

Regarding the current institutional mechanism, both the role and the organizational structure of two institutions, namely UN and IAEA should be revised. UN should take the enforcement role to consolidate nonproliferation norm. The legal framework for the enforcement capability of the 
UN could also be backed by the political power, which should make the cheaters to be faced with political isolation as a result of the UN Resolution.

Since the UN Security Council determines the existence of a threat to the peace or act of aggression, consolidating a universal nuclear nonproliferation norm is also expected to be taken as a primary role by the UN Security Council. Such a role of the UN would certainly require the readjustment of decision-making process in the Security Council. Regarding the nuclear proliferation at least, all 15 members of the Council without making a distinction between permanent and temporary members should have one vote without veto power. This re-adjustment will increase confidence between states and create a ground for the UN to deal with not only the nuclear program of the non-nuclear weapon states, but also the existence of nuclear arsenals of the nuclear weapons states, including both their strategic and tactical nuclear weapons. In the graphic, the suggested UN role is illustrated with one-way red arrows, which implies the enforcement power of the UN on states in order to preserve and consolidate nonproliferation norms and rules. If states will not follow international norms, they should know in advance that political isolations as a result of political and economic sanctions would be the inevitable consequence.

Consolidating the enforcement role of the UN, its verification process should certainly be strengthened. How UN would get reliable information on nuclear proliferation? As currently happening, the UN resolutions should be based on the IAEA reports. This mechanism is illustrated with one-way arrow goes from the IAEA to the UN in the Graphic. In addition, regional organizations should be an auxiliary route in informing UN. Consequently, regional organizations will strengthen nonproliferation efforts sharing the reports of their own inspections with the IAEA and the UN concurrently. This mechanism is illustrated with one-way arrow goes from the regional organizations both to the IAEA and the UN in the Graphic.

IAEA is another organization at the international level that works for preventing nuclear proliferation. In the new mechanism, IAEA would continue its verification function over both the non-nuclear weapon states and nuclear weapon states. However, the most important point is to get the acceptance of key states, which have been suspected or known of having nuclear weapon capability. In that respect, the creation of regional organizations, which will share information with the IAEA and UN, became crucial.

One of the current challenges to the nonproliferation regime is resulted from the will of developing states to retain their right under the NPT to possess nuclear fuel cycle technologies. What complicates the situation is the limitation on the verification system of the IAEA over the enrichment process at the indigenous nuclear reactor. The spread of nuclear fuel cycle technologies, notably for uranium and reprocessing spent fuel to separate plutonium, increases the risk of nuclear proliferation giving states to produce fissile materials for weapons. Thus, El Baradei defined the spreading of nuclear fuel cycle technologies as the 'Achilles' heel of the nuclear nonproliferation regime.' ("Multilateral Approaches to The Nuclear Fuel Cycle," Expert Group Report Submitted to The Director General of the International Atomic Energy Agency, INFCIRC, 
640, 22 February 2005: 17) As mentioned by Diyakov (2010, pp. 117-125), spreading nuclear fuel cycle technologies is not a new problem and increases the risk of illegal transfer of sensitive technologies to other entities, diversion of nuclear materials from declared facilities, having a clandestine military program with the undeclared fuel cycle activities and withdrawal from NPT in order to continue nuclear program from military purposes. Increasing the number of states that seek for their own fuel cycle led El Baradei to appoint an international group of experts to evaluate possible multilateral approaches to the civilian nuclear fuel cycle in 2004. ("Multilateral Approaches to The Nuclear Fuel Cycle," Expert Group Report Submitted to The Director General of the International Atomic Energy Agency, INFCIRC, 640, 22 February 2005, pp. 4-5) According to that report, multilateral approach would satisfy both of the following objectives; 'assurance of nonproliferation' and 'assurance of supply and services.' ("Multilateral Approaches to The Nuclear Fuel Cycle," Expert Group Report Submitted to The Director General of the International Atomic Energy Agency, INFCIRC, 640, 22 February 2005, p. 5)

Regarding the problems caused by the spreading of nuclear fuel cycle technologies, an International Nuclear Fuel Bank would provide an efficient institutional mechanism to prevent states from developing their own enrichment activities. Even though multilateral mechanism for nuclear fuel cycle had already been suggested in several times, none of them had been implemented. For instance, France, Germany, the Netherlands, Russia, the United States and United Kingdom had already suggested guaranteeing international fuel supply. Establishment of a fuel bank under the auspices of the IAEA and a multinational fuel center, which would be realized as a result of both converting national fuel cycles to multinational enterprises and creating regional multinational fuel centers, were also recommended. Last but not least, Global Nuclear Infrastructure Initiative that is proposed by Russia was another inconclusive attempt to create multilateral nuclear fuel cycle centers. Since analyzing all these proposals are out of the scope of this paper, it is sufficient to mention here that one of the main oppositions of the non-nuclear weapon states has been based on the rejection of being dependent on another country for acquiring enriched uranium. In that sense, an international fuel bank would create a ground for all states to acquire enriched uranium equally, which is illustrated with one-way green arrow goes from the states to the bank in the Graphic. This new mechanism would contribute to increase confidence between states not only providing equal rights to access to nuclear energy, but also facilitating the verification process over a state's nuclear activities by offering storage and disposal of spent fuel.

In contrast to the current mechanism, it is necessary to create regional organizations, which should work together with the international institutions such as UN and IAEA, to prevent nuclear proliferation. At the 2005 NPT Review Conference, El Baradei proposed the regional multinational centers as a part of a mechanism for the multilateral nuclear fuel cycle at the 2005 NPT Review Conference. (Kerr and Pomper, 2005) The tasks of regional organizations could be based on two objectives. The first would be to create a platform for dialogue, facilitating direct communication between states in order to reduce tensions and conflicts. Since the regional conflicts have been one of the main reasons for nuclear proliferation, specifically for threshold states (Zaborsky, 1998, p. 96), regional organizations would remove security dilemma, creating 
more transparency and building confidence between regional states. The second would be to consolidate verification measures. At the regional level, the initiatives have been mainly based on the establishment of nuclear-weapon free zone. However, resistance of threshold and non-nuclear weapon states jeopardizes these initiatives to be successful. Therefore, the formation of regional nuclear fuel cycles would contribute to harmonize nuclear policies of these states. In addition, it would increase transparency and confidence about nuclear issues, encouraging cooperation on peaceful uses of nuclear energy. In that sense, one of the initiatives about the regionalization of nonproliferation policies is the Arab Atomic Energy Agency. Even though it has been dormant for a long time, the Riyadh Summit in 2007 and Doha Summit in 2009 underlined the necessity for an effective in order to encourage cooperation for the development of peaceful nuclear activities in the Arab world. (Shaker, 2010, p. 97) What is important here is becoming a party of regional nonproliferation institutions should be perceived as an inevitable result of accepting nonproliferation norms. In other words, regional organizations should also take a complimentary role to the international organizations in order to consolidate nonproliferation norms. This makes regional organizations to be as important as international organizations, which is now missing in the current institutional mechanism.

Regarding the nuclear nonproliferation considerations, regional organizations would serve to reduce nuclear motivations of states and to verify peaceful nuclear activities of their members, which will contribute to create mutual trust between states. At the suggested mechanism, regional organizations would take active role in the verification process with the participation of inspectors from the party states. Such an action was taken by Brazil and Argentine, for instance, when they signed an agreement whereby they abandoned the acquisition of nuclear weapons. They agreed to carry out verification measures with their own inspectors with the Agency's inspectors. (Valesquez, 2004, p. 29) Implying the same mentality of Brazil and Argentine, the participation of a party state's inspector, who is independent from the IAEA's personnel, would contribute to increase confidence towards the verification system. Furthermore, the verification measures of regional organizations would be expected to strengthen the hands of the UN in implementing sanctions.

At the domestic level, both nuclear and non-nuclear weapon states should be treated equally at this new mechanism. Both of them have to acquire nuclear fuel from the international bank for their own nuclear energy program; have to become a member of the regional organizations and have to be subject of the UN sanctions if they violated the nonproliferation norm. In contrast to the current nonproliferation regime, the distinction between nuclear and non-nuclear weapon states should be eliminated.

\section{Conclusion}

Although the international nuclear nonproliferation efforts have existed for nearly fifty years, the current institutional mechanisms have not yet efficiently prevented the proliferation of nuclear 
weapons. This article analyzed the effectiveness of international nuclear regime measuring its capability of problem-solving, reducing nuclear motivations of states, providing legal framework and verification process, and creating and consolidating normative principles. While the nuclear regime could partly be seen as effective regarding the low number of nuclear weapon states than the expected numbers in 1960s, it faces with serious challenges in solving the nuclear problem. One of the challenges emerges because of the lack of universal acceptance of the international treaties and organizations. The regime has also not effectively addressed to reduce the nuclear motivations of states. Even though it has provided legal framework and verifying process, there are still difficulties to detect nuclear activities for military purposes. Lastly, the regime has effectively created the non-use and deterrence norms, while failed to create and consolidate the nonproliferation norm, based on total elimination of nuclear weapons. Since the existence of nuclear weapons is still ignored by the current nonproliferation regime, it ineffectively addresses to the increasing risk of a nuclear attack by the new actors.

As mentioned, the lack of universal acceptance of the treaties and organizations, the perception of the NPT as a discriminatory treaty, the challenges in the verification process, continuation of nuclear motivations by some states and finally the continuation of the role of nuclear weapons, notably tactical nuclear weapons, in the military of the nuclear weapons states have made international nonproliferation efforts to become ineffective. Most importantly, the lack of political wills of states, including all threshold, non-nuclear - and nuclear-weapon states, to prevent nuclear proliferation made all nonproliferation initiatives to be inconclusive. Since the answer is negative to the question of whether living with nuclear weapons is safe, conducting rigid international policies to eliminate all nuclear weapons without exception, rather than seeking the ways to live with these weapons, is really necessary.

It is seen that the international nonproliferation regime has been based on the non-use and deterrence norms of nuclear weapons. However, the spreading of tactical nuclear weapons and the emergence of the terrorist organizations as the most likely user of nuclear weapons in near future, clouds the success of these norms to prevent nuclear attacks. Therefore, the nonproliferation norm of nuclear weapons, which should equate the absence of nuclear weapons with protecting human rights, has to be urgently consolidated. Firstly, the norm-setting process of the nuclear nonproliferation should be focused on. Within that framework, the active involvement of UN and regional organizations in the norm-setting process should be created. Secondly, an alternative multilateral mechanism should be established to address effectively to the current proliferation challenges, because the establishment of normative structure would be inconclusive without the support of institutional mechanisms. At the international level, UN, IAEA and an International Fuel Bank would function collaborating with each other. Their primary task should be to build nonproliferation norms by supplying nuclear fuel for civilian purposes and to provide verification measures to prevent nuclear activities for military purposes. At the regional level, regional organizations would contribute to the consolidation of nonproliferation norms by supporting international verification measures and increasing transparency and mutual trust between countries. At the domestic level, all countries are expected to oblige to fulfill the 
requirements of nonproliferation norms and rules, as a result of accepting these norms and rules for universal human rights.

This article aimed to shed light on the ineffectiveness of international nuclear regime and to open a discussion over the possible institutional mechanisms, suggesting an alternative mechanism that would work for nuclear nonproliferation at the international, regional and domestic levels. Keeping in mind the weaknesses of this suggested mechanism, discussing alternative institutional mechanism for nonproliferation concerns is an urgent issue for human rights. Before reaching to the point, at which U-turn is impossible, the existence of nuclear weapons should be perceived as a threat to the universal human rights.

\section{BIBLIOGRAPHY}

Diyakov, A. S. (Winter 2010) "The Nuclear "Renaissance" \& Preventing the Spread of Enrichment \& Reprocessing Technologies: A Russian View”, Daedalus 139 (1), 117-125.

Valezquez, A. C. S. (December 2004) "Civil-Military Affairs and Security Institutions in the Southern Cone: The Sources of Argentine-Brazilian Nuclear Cooperation", Latin American Politics and Society 46 (4): 29.

Braun, C. and Chyba F. C. (Fall 2004) "Proliferation Rings: New Challenges to the Nuclear Nonproliferation Regime”, International Security 29 (2): 42.

Eyre, D. P. and Suchman M. C. (1996) "Status, Norms and the Proliferation of Conventional Weapons: Institutional Theory Approach", In Peter J. Katzenstein (ed.) The Culture of National Security: Norms and Identity in World Politics, New York: Columbia University Press, 86-87.

Press, D. G., Sagan, S. D. and Valentino B. A. (February 2013) Atomic Aversion: "Experimental Evidence on Taboos, Traditions and the Non-Use of Nuclear Weapons", American Political Science Review http:// iis-db.stanford.edu/pubs/24013/FINAL_APSR_Atomic_Aversion.pdf (Accessed 12 January 2014)

Kristensen H. M. (May 2012) "Non-Strategic Nuclear Weapons", Federation of American Scientists, Special Report 3 http://devposse.gatech.edu/sites/devposse.gatech.edu/files/Non-Strategic\%20Nuclear\%20 Weapons.pdf (Accessed 15 January 2014)

Doyle J. E. (February-March 2013) "Why Eliminate Nuclear Weapons?", Survival: Global Politics and Strategy: 16.

Dhanapala J. (Fall 2001) "Multilateralism and the Future of the Global Nuclear Nonproliferation Regime", The Nonproliferation Review: 1-2.

Bunn M. (September 2006) “A Mathematical Model of the Risk of Nuclear Terrorism”, Annals of the American Academy of Political and Social Science 607: 103-120.

'Multilateral Approaches to The Nuclear Fuel Cycle', Expert Group Report Submitted to The Director General of the International Atomic Energy Agency, INFCIRC 640 (22 February 2005).

Shaker M. I. (Winter 2010) "Nuclear Power in the Arab World \& The Regionalization of The Nuclear Fuel Cycle: An Egyptian Perspective”, Daedalus 139 (1): 93-104.

Tannenwald N. (Summer 1999) "The Nuclear Taboo: The United States and the Normative Basis Nuclear Non-Use", International Organization 53 (3).

Young, Oran R. and Levy, Marc A. (1999) “The Effectiveness of International Environmental Regimes” in Oran R. Young (ed.), The Effectiveness of International Environmental Regime: Causal Connections and Behavioral Mechanisms USA: MIT Press, 1-33. 
“Obama Prague Speech on Nuclear Weapons", (April 2010) vii http://www.huffingtonpost.com/2009/04/05/ obama-prague-speech-on-nu_n_183219.html (Accessed 9 July 2013)

Homan, P. (2013) "Exploring the Nex Generation of Proliferators: Why Venezuela is not the Next Iran", The Nonproliferation Review 20/1: 63.

Kerr, P. and Pomper, M. (4 February 2005) "Tackling the Nuclear Dilemma: An Interview with IAEA Director-General Mohamed ElBaradei”, Arms Control Association http://www.armscontrol.org/ act/2005_03/ElBaradei (Accessed 5 January 2014)

Price, R. and Tannenwald, N. (1996) "Norms and Deterrence: The Nuclear and Chemical Weapons Taboos", In Peter J. Katzenstein (ed.) The Culture of National Secuirty: Norms and Identity in World Politics, New York: Columbia University Press, 138.

McCoy, R. (October-December 2007) “The Continuing Risk of Nuclear War", Medicine, Conflict and Survival 23 (4): 261.

Sagan, S. D. (Winter 1996/97) "Why Do States Build Nuclear Weapons?: Three Models in Search of a Bomb", International Security 21 (3): 55.

Sauer, T. (2006) “The Nuclear Nonproliferation Regime in Crisis," Peace Review: A Journal of Social Justice 18 (3): 333-340.

Pullinger, S. (October-November 2003) "U.S. Policy: WMD, Good and Bad", Disarmament Diplomacy.

Zaborsky, V. (Fall 1998) "What to Control and How to Control: Nonproliferation Dilemmas", World Affairs 161 (2): 92-98. 